\title{
AN EXPLORATORY ANALYSIS ON THE IMPACT OF INSTITUTIONAL-SPECIFIC CUM MACROECONOMIC INDICATORS ON THE NON-PERFORMING ASSETS OF SBI AND ASSOCIATE BANKS IN INDIA
}

\author{
S. Gokul Kumar ${ }^{1}$, M. Jayanthi ${ }^{2}$, K. Subramani ${ }^{3}$ and A. Prasanth ${ }^{4}$ \\ ${ }^{1,3,4}$ School of Management Studies, Bannari Amman Institute of Technology, India \\ ${ }^{2}$ School of Commerce, PSG College of Arts and Science, India
}

\begin{abstract}
The research aims at analyzing the influence of 5 industry-specific and 4 macroeconomic factors on the non-performing assets of SBI and Associate Banks in India by collecting the relevant data for a period of 10 years ranging from 2006-07 to 2015-16. The results of multiple correlation analysis ensured the positive correlation between Repo Rate (RR), Reverse Repo Rate (RRR), Unemployment Rate (UR) and NonPerforming Assets (GNPATA) whereas the variables such as Capital Adequacy Ratio (CAR), Cash Reserve Ratio (CRR) Prime Lending Rate (PLR), Money Supply (MS) and Gross Domestic Product Growth Rate (GDPGR) showed a negative impact on the non-performing assets. The Granger Causality Test confirmed the association of CAR, CRR, RRR, $I R, M S, U R$ and GDPGR with the non-performing assets whereas the remaining variables such as $P L R$ and $R R$ portrayed a negative relationship with the non-performing assets. Further the Johansen Cointegration Test results witnessed that all the institutional-specific and macroeconomic variables are co-integrated with the non-performing assets of SBI and Associate Banks in India.
\end{abstract}

Keywords:

Institutional-Specific, Macroeconomic, Non-Performing Assets, SBI, Associate Banks

\section{INTRODUCTION}

The Non-Performing Assets (NPAs) hold the key position in determining the profitability of banks all around the world as it is huge burden for the any kind of bank and a considerable amount of banks' profit should be set aside in the name of NPA provision also. The industry-specific variables such as Capital Adequacy Ratio (CAR), Cash Reserve Ratio (CRR), Repo Rate (RR), Reverse Repo Rate (RRR), Prime Lending Rate (PLR) has a considerable impact on the trend of bank NPAs. Further, the macroeconomic variables such as Inflation Rate (IR), Gross Domestic Product Growth Rate (GDPGR), Unemployment Rate (UR) and Money Supply (MS) plays a predominant role in influencing the NPAs of SBI and associate banks in India. These study variables have been selected based on the past literatures only. The study data has been collected for a period of 10 years from 2006-07 to 2015-16, the source being the various statements and documents published by the Reserve Bank of India (RBI) from time-to-time in its official website and other relevant sources.

With this brief introductory note, the study is framed in the following mode. Section 2 deals with the summary of past literatures, section 3 sketches the study design, section 4 is composed with the research findings, suggestions, conclusion followed by the section 5 which brings an end to the study with the resources being referred for the research.

\section{REVIEW OF LITERATURE}

Das and Ghosh [1] inspected the determinants of credit risk in the Indian state-owned banks during the period 1993-94 to 200405 , by adopting the robust test. The study aimed at defining the determinants of credit risk in the Indian state-owned banks macroeconomic and microeconomic variables. The results showed that the macroeconomic factors such as bank growth rate, GDP growth, operating cost, bank size and real loan growth rate had large impact on the problematic lending. Further the study also suggested that the loan borrower had to be screened regularly in order to avoid the NPAs. Then, the huge banks lean towards great loan problems in terms of their size of operations. In addition to that, it was also found that the surplus progression loan levels and deteriorated levels of bank capital had to be much concerned for avoiding the future problems.

$\mathrm{Li}$ [2] examined the determinants of banks' profitability and its implication on risk management practices during the period 1998-99 to 2005-06, by applying the descriptive statistics and regression analysis. The research targeted on determining the influence of microeconomic and bank specific factors on the profitability of banks measured in terms of return on average assets. The regression analysis results revealed that the allocation for NPA had a negative association affecting the profitability of banks and the effect of liquidity on profits couldn't be determined. The healthy capital structure was declared the main influent of banks' profitability which would lead to a better functioning by reducing the cost of borrowing. Further, it was found that the macroeconomic variables such as inflation rate, interest rate and GDPGR had no association with that of the profitability of banks.

Vong and Chan [3] analyzed the determinants of bank profitability in Macao, during the period 1992-93 to 2006-07, by using the ratio analysis method. The study mainly focused on finding the impact of bank characteristics, macroeconomic and financial structure variables on the performance of banks in Macao. The ratio analysis results showed that the most important factor having the higher effect on the profitability was capital power. This would lead to lower risk which in turn would result in increase in profitability. Further the asset quality of the banks in terms of NPA provisions resulted in negative association with the profitability of banks. The banks with lesser linkage of retail deposit performed better than that of those banks with higher level of retail deposits. In addition, it was also found that the inflation rate was the only microeconomic factor which had the affirmative association with the profitability of the banks.

Sufian and Chong [4] investigated the determinants of bank profitability in a developing economy with empirical evidence 
from the Philippines during the period 1989-1990 to 2004-05, by using the correlation matrix and multivariate regression models. The research was very particular about the profitability influents and its level of impact on the profitability banks. The results revealed that all the bank-specific variables had a reasonable influence on the profitability. Further it was found that the factors such as bank size, expense preference behavior and credit risk had adverse relationship whereas the capitalization and non-interest income had a direct association with the profit level of banks in Philippines. The macroeconomic factors like supply of money, capitalization of stock market and economic growth had considerable impact while the rate of inflation had no impact on the profitability of banks.

Mirzaei and Mirzaei [5] analyzed the bank-specific and macroeconomic determinants of profitability in the Middle Eastern banking during the period 1998-99 to 2007-08, using the OLS and GMM techniques. The analysis mainly focused on examining the determinants of profitability and to measure the impact of bank specific and macro-economic factors on the profitability of banks. The results showed capital strength, liquidity and efficiency as the determinants of profitability. The dynamic model exposed a non-linear association among the size and profitability of banks. Further there was no mark of backing for the traditional SCP hypothesis as per the static model. In addition, the results revealed that the off-balance-sheet activities had a negative impact on the profitability of banks whereas the inflation didn't have any sort of impact on banks' profitability.

Sufian [6] interrogated the profitability of Korean Banking Sector with panel evidence on bank-specific and macroeconomic determinants during the period 1991-92 to 2002-03, by adopting the ratio analysis. The study eyed on determining the profitability of banks in Korea by considering the bank-specific and macroeconomic influents. The results exhibited that the banks with low liquidity earned high profits whereas the banks with high liquidity realised only lesser profits. Further the ratio analysis showed that the diversification of funds to the derivative products and non-interest income activities had a direct association with the profitability of banks. The influence made by credit threat and overhead cost was very low displaying an inverse association with the profitability of banks in Korea.

Ali et al. [7] critically examined the bank-specific and macroeconomic indicators of profitability with empirical evidence from the commercial banks of Pakistan during the period 2005-06 to 2008-09, by applying the descriptive, correlation and regression analysis. The study utilized the return on assets and return on equity as the profitability measures. The correlation analysis revealed a favorable association among efficient asset management and economic growth with profitability in ROA as well as in ROE models. The profitability of the banks were affected by expanded credit risk and capitalization in the return on assets model whereby the operating efficiency inclines in increased profitability level as per the return on equity model.

Thota [8] scrutinized the determinants of commercial banks profitability in India during the period 1998-99 to 2010-11, by applying the empirical and econometric model. The study eyed on examining the macroeconomic and bank-specific factors that affects the profitability of the Indian commercial banks. The results expressed that the internal as well as the external factors affect the profitability of commercial banks irrespective of their proprietorship. Further it was found that the size of the bank and its liquidity position didn't have any impact on the return on asset or return on equity as a profitability measure. The credit risk of the private and foreign banks had a direct association with their profitability. In addition it was determined that the macroeconomic factors didn't possess any impact on the ROE and had a considerable impact on the ROA.

Weerasinghe and Perera [9] explored the profitability determinants of commercial banks in Sri Lanka during the period 2000-01 to 2010-11, by using the multiple panel regression. The study aimed at determining the influents of banks' profitability and to investigate the bank-specific factors' impact on the profitability of banks. It was obvious that the performance of banking sector was conquered by commercial banks in Sri Lanka. The results showed that liquidity, interest rate, operating expenses and size of the bank had a considerable impact on the profitability of banks measured by ROA. Further it was noted that the banks with high efficiency and lower liquidity had improved profitability. In addition, the credit risk didn't have any impact on the profitability whereas the macroeconomic factor interest rate had high impact on the profitability of commercial banks in Sri Lanka.

Prasanna [10] investigated the determinants of nonperforming loans in Indian banking system during the period 2000-01 to 2011-12, with the help of Panel Data Modeling tool. The data pertaining to 31 banks was taken for the study. The bivariate regression analysis was used to find the association of each macroeconomic variable upon the gross and net NPL ratio. The panel data modeling tool disclosed that high growth in savings and GDP results in lower NPLs whereas increase in interest and inflation rate leads to further increase in NPLs. Further it was observed that GDP at factor cost, PCI growth rate and foreign trade proxies had a negative connection with the NPLs. The multiple regression result revealed that macroeconomic variables backed $52 \%$ of variations in NPLs and the rest $48 \%$ was added by bank specific factors.

Roy [11] scrutinized the determinants of non-performing assets in India during the period 1995-96 to 2011-12, using the Panel Regression tool. The NPAs continues to shake the economies all around the world from time to time. The study consisted of 4 bank specific variables and 8 economic factors. The panel regression, fixed effect agrees assessing the influence of certain macroeconomic elements on the NPA. The result revealed by this study was comparatively in the same line to that of the study conducted in other regions also. The Indian banking sector was fronting the hassle of their asset superiority as the GDP growth deteriorated and Indian rupee saw precipitous downgrading. The panel regression denoted that the growth in GDP, varying exchange rate and global volatility had major impact on the NPA of Indian Banking Sector.

Dhar and Bakshi [12] studied the factors that influence the variability of loan losses (NPAs) of public sector banks in India for the period 2000-01 to 2004-05, using the Panel Regression tool. The emphasis was laid on macroeconomic factors or a combined set of macroeconomic and bank-specific factors. The panel regression tool revealed that certain bank-specific factors like net interest margin and capital adequacy ratio exhibits negative and significant impact on gross non-performing advances ratio of Indian banks. The advances had a positive relationship with NPA ratio and the relationship was statistically 
significant also. The panel approach considered both the spatial and time dimensions of observations which revealed that banks must distillate on the variables such as advances to the SEN, NIM and CARs to rheostat the complication of loan losses.

Biswas [13] investigated the management of non-performing assets in State Bank of India functioning in the Barak Valley Districts of Assam. This study aimed at examining the trends and patterns of NPAs in SBI. Further it focused on identifying the various factors contributing to the NPAs, existing NPA management system and to suggest measures to reduce the level of NPAs in SBI. The research findings suggested that the factors such as lack of follow up, project failure, inadequate credit financing, poor legal framework, natural calamities, low income generation, diversification of funds, high rate of interest and willful default contributed to the NPAs of SBI. Finally the study results proposed the NPA management measures such as maintaining asset quality, post-sanction supervision, special training to the bank employees on managing NPAs and reward system for better performance of employees.

Thirumalaimuthu [14] scrutinized the management of nonperforming assets in banks with reference to selected public sector banks in Tirunelveli district. The study eyed on concepts, significance and causes of NPAs. Further it analyzed the various reasons for NPAs, perception of borrowers with respect to default, recovery experience of banks, impact of NPA on the banking sector and suggested suitable measures based on the research findings to curb the level of NPAs in future. The study results suggested that all the 3 banks namely State Bank of India, Canara Bank and Indian Overseas Bank has to follow the measures such as working effectively by having regular follow-up of their customers, sharing of credit information among banks to avoid future default, maintain healthy relationship with the customers, assisting the borrowers in developing entrepreneurial skills, providing tax incentives to the customers, adopting latest technology for reducing transaction costs involved in sanctioning loans to the priority sectors, maintaining compromise settlement schemes, proper credit assessment and risk management mechanism followed by the banks.

Hence, this research has made an attempt to study the prevailing gap in the earlier studies and minimized the research gap by comparing the various institutional-specific variables and macroeconomic variables with the non-performing assets of SBI and Associate Banks in India.

\section{RESEARCH DESIGN}

In this session, we will discuss about the objectives of the study, hypotheses tested, research technique being adopted, the various statistical tools used, statistical equations and the predictable association that exists among the dependent and independent variables of the study.

\subsection{OBJECTIVES OF THE STUDY}

- To ascertain the association of institutional-specific and macroeconomic indicators with the non-performing assets of SBI and Associate Banks in India.

- To define the impact of institutional-specific and macroeconomic indicators on the non-performing assets of SBI and Associate Banks in India.

\subsection{HYPOTHESES STATEMENT}

$\mathbf{H}_{0}$ : There is no significant relationship between the institutional-specific cum macroeconomic indicators and the nonperforming assets of SBI and Associate Banks in India. $\mathrm{H}_{\mathrm{a}}$ : There is significant relationship between the institutional-specific cum macroeconomic indicators and the non-performing assets of SBI and Associate Banks in India.

\subsection{RESEARCH METHODOLOGY}

This research has been carried out by compiling the banking and economic data related to all the 6 banks of the study, collected for a period of 10 years ranging from 2006-07 to 2015-16. The source of the data being secondary, it was collected from the website of RBI and other available resources based on the research convenience of the researchers.

The data so collected has been analyzed to determine the impact of explanatory variables on the explained variable, by applying the forthcoming statistical tools:

- Descriptive Statistics

- Multiple Correlation Analysis

- Augmented Dickey Fuller Unit Root Test

- Granger Causality Test and

- Johansen Co-integration Test

Table.1. Predictable Association between the Independent and Dependent Variables

\begin{tabular}{|c|c|c|}
\hline Explained & Explanatory & $\begin{array}{c}\text { Expected } \\
\text { Sign. }\end{array}$ \\
\hline \multirow{4}{*}{$\begin{array}{c}\text { Gross Non- } \\
\text { Performing } \\
\text { Assets to } \\
\text { Total }\end{array}$} & CAR - Capital Adequacy Ratio & Negative \\
\cline { 2 - 3 } \begin{tabular}{c} 
Advances \\
\cline { 2 - 3 } (GNPATA)
\end{tabular} & RRR - Cash Reserve Ratio & Negative \\
\cline { 2 - 3 } & RLR - Reverse Repo Rate & Negative \\
\cline { 2 - 3 } & $\begin{array}{c}\text { GDPG }- \text { Inflation Rate } \\
\text { Product Gross Domestic }\end{array}$ & Negative \\
\cline { 2 - 3 } & UR - Unemployment Rate & Positive \\
\cline { 2 - 3 } & MS - Money Supply & Positive \\
\cline { 2 - 3 } & Negative \\
\hline
\end{tabular}


Table.2. Descriptive Statistics Result Summary of Institutional-Specific and Macroeconomic Variables with the Non-Performing Assets of SBI and Associate Banks in India

\begin{tabular}{|c|c|c|c|c|c|c|c|c|c|c|}
\hline Variables & GNPATA & CAR & CRR & PLR & RRR & RR & IR & MS & GDPGR & UR \\
\hline Mean & 0.4586 & 1.0941 & 0.6975 & 1.0387 & 0.7612 & 0.8444 & 0.8960 & 6.1807 & 0.8780 & 0.9326 \\
\hline Median & 0.4745 & 1.0934 & 0.6878 & 1.0216 & 0.7842 & 0.8751 & 0.8864 & 6.2006 & 0.8627 & 0.9332 \\
\hline Maximum & 0.9156 & 1.1732 & 0.8751 & 1.1202 & 0.9165 & 0.9294 & 1.1752 & 6.3903 & 0.9809 & 1.0334 \\
\hline Minimum & -0.0603 & 1.0162 & 0.6021 & 0.9777 & 0.5441 & 0.6990 & 0.6911 & 5.9358 & 0.7482 & 0.8325 \\
\hline Std. Dev. & 0.2265 & 0.0373 & 0.0931 & 0.0490 & 0.1185 & 0.0776 & 0.1490 & 0.1437 & 0.0737 & 0.0675 \\
\hline Skewness & -0.1240 & 0.0105 & 0.4322 & 0.6322 & -0.9199 & -1.1183 & 0.3392 & -0.2430 & -0.0701 & 0.0910 \\
\hline Kurtosis & 2.1844 & 2.2750 & 1.9607 & 1.9677 & 2.7296 & 2.7607 & 1.9871 & 1.8899 & 1.8557 & 1.8281 \\
\hline Jarque-Bera & 1.8169 & 1.3151 & 4.5677 & 6.6611 & 8.6442 & 12.6480 & 3.7155 & 3.6715 & 3.3229 & 3.5162 \\
\hline Probability & 0.4031 & 0.5181 & 0.1019 & 0.0358 & 0.0133 & 0.0018 & 0.1560 & 0.1595 & 0.1899 & 0.1724 \\
\hline Sum & 27.5177 & 65.6438 & 41.8496 & 62.3201 & 45.6704 & 50.6640 & 53.7598 & 370.8423 & 52.6807 & 55.9556 \\
\hline Sum Square Deviation & 3.0256 & 0.0819 & 0.5116 & 0.1419 & 0.8288 & 0.3554 & 1.3105 & 1.2182 & 0.3202 & 0.2691 \\
\hline
\end{tabular}

\section{RESULTS AND DISCUSSION}

\subsection{FINDINGS OF THE STUDY}

This session summarizes the results of all the statistical tools applied such as Descriptive Statistics, Multiple Correlation Analysis, Augmented Dickey Fuller Test, Granger Causality Test and Johansen Co-integration Test. Based on the research findings, valid suggestions are given to the SBI and Associate Banks in India for decreasing their level of NPAs and to improvise in terms of profitability.

The Table. 2 represents the consolidated results of descriptive statistics of SBI and Associates for the study period of 10 years from 2006-07 to 2015-16, which explains the influence of independent variables (Institutional-specific and Macroeconomic) on that of the dependent variables (GNPATA). The Money Supply (MS) holds the maximum mean value (6.1807) followed by Capital Adequacy Ratio (1.0941) and Prime Lending Rate (1.0387). On the other hand, the Inflation Rate has the highest standard deviation of 0.1490 queued by Money Supply (0.1437) and Reverse Repo Rate (0.1185), which clearly proves their respective control on the Gross Non-Performing Assets of SBI and Associates during the study period.

All the study variables are good enough to study their impact on the GNPA, as they have only fewer fluctuations in their values during the entire period of study. Similarly, the RRR is very much unreliable with the minimum and maximum values of 0.5441 and 0.9165 respectively. The NPA of SBI and Associate Banks has been measured in terms of GNPATA which showed minimum and maximum values of -0.0603 and 0.9156 .

The Table. 3 reveals the results of multiple correlation analysis of 5 institutional-specific variables considered for the study. It is quite clear that the variables such as CAR, CRR (0.4559) and PLR (0.4121) has positive correlation among them whereas the variables like RR (-0.3906) and RRR (-0.4475) has negative relationship. At the same time, there exists a positive relationship for CRR-PLR (0.5652) and also between the variables RR and RRR (0.9296). On the other hand, the variables such as RR
(0.4594) and RRR (0.5692) had positive association with the GNPATA whereas the other 3 variables CAR (-0.4338), CRR ($0.7535)$ and PLR (-0.6718) has negative relationship with the GNPATA of State Bank of India and Associate banks over the study period of 10 years ranging from 2006-07 to 2015-16.

Table.3. Multiple Correlation Analysis of Institutional-specific Variables

\begin{tabular}{|c|c|c|c|c|c|}
\hline Variables & CAR & CRR & PLR & RR & RRR \\
\hline CAR & 1 & & & & \\
\hline CRR & .4559 & 1 & & & \\
\hline PLR & .4121 & .5652 & 1 & & \\
\hline RR & -.3906 & -.1852 & -.5076 & 1 & \\
\hline RRR & -.4475 & -.3630 & -.6276 & .9296 & 1 \\
\hline
\end{tabular}

Table.4. Multiple Correlation Analysis of Macroeconomic Variables

\begin{tabular}{|c|c|c|c|c|}
\hline Variables & IR & MS & UR & GDPGR \\
\hline IR & 1 & & & \\
\hline MS & -.3868 & 1 & & \\
\hline UR & .4218 & .0672 & 1 & \\
\hline GDPGR & -.2609 & -.6016 & -.2188 & 1 \\
\hline
\end{tabular}

The Table.4 explains the results of multiple correlation analysis calculated for the 4 macroeconomic variables taken for the study. From the results, it can be understood that the variables IR and UR (0.4218) are positively correlated along with the other 2 variables MS-UR (0.0672) whereas the other 2 variables such as MS (-0.3868) and GDPGR (-0.2609) are negatively correlated with IR. At the same time, the Money Supply (0.7992) alone is said to be positively correlated with GNPATA whereas the other 3 variables such as IR (-0.5315), UR (-.2040) and GDPGR (0.4820 ) are negatively correlated with the GNPATA of SBI and Associate banks during the study period of 10 years. 
Table.5. Augmented Dickey Fuller Unit Root Test of Institutional-specific Variables and Non-Performing Assets

\begin{tabular}{|c|c|c|c|c|}
\hline Variables & Level & $\begin{array}{c}\text { First } \\
\text { Difference }\end{array}$ & $\begin{array}{c}\text { Second } \\
\text { Difference }\end{array}$ & $\begin{array}{c}\text { Order of } \\
\text { Integration }\end{array}$ \\
\hline GNPATA & -5.5934 & -7.5213 & -14.3475 & I (1) \\
\hline CAR & -4.6588 & -9.7607 & -11.4951 & I (1) \\
\hline CRR & -7.7964 & -5.6851 & -13.4867 & I (1) \\
\hline PLR & -5.7051 & -7.3297 & -8.4220 & I (1) \\
\hline RR & -6.0987 & -9.2753 & -9.8468 & I (1) \\
\hline RRR & -5.4209 & -7.3132 & -13.2692 & I (1) \\
\hline
\end{tabular}

Augmented Dickey Fuller (ADF) Unit Root Test is the statistical tool which is used to examine the extent of association that exists among the independent variables considered for the study. The Table.5 clearly explains that all the 5 institutionalspecific variables such as CAR, CRR, PLR, RR and RRR as well as the dependent variable GNPATA are stationary (non-existence of unit root) at first difference with the integration order of $I(1)$. Hence, the variables can be taken for the further analysis such as Granger Causality Test and Johansen Co-integration Test.

Table.6. Augmented Dickey Fuller Unit Root Test of Macroeconomic Variables and Non-Performing Assets

\begin{tabular}{|c|c|c|c|c|}
\hline Variables & Level & $\begin{array}{c}\text { First } \\
\text { Difference }\end{array}$ & $\begin{array}{c}\text { Second } \\
\text { Difference }\end{array}$ & $\begin{array}{c}\text { Order of } \\
\text { Integration }\end{array}$ \\
\hline GNPATA & -5.5934 & -7.5213 & -14.3475 & I (1) \\
\hline IR & -5.5413 & -5.8521 & -6.8013 & I (1) \\
\hline MS & -4.4421 & -8.3691 & -8.9103 & I (1) \\
\hline UR & -5.8340 & -8.9054 & -12.2028 & I (1) \\
\hline GDPGR & -5.6742 & -7.8215 & -13.1211 & I (1) \\
\hline
\end{tabular}

The Table. 6 depicts the ADF test results of macroeconomic variables and the GNPATA of SBI and Associate Banks in India. The above result undoubtedly elucidates the non-existence of unit root by confirming the stationarity at first difference with the integration order of $I(1)$. Thus, all the 4 macroeconomic variables such as IR, MS, UR and GDPGR along with the dependent variable GNPATA can be further used for the application of other statistical tools such as Granger Causality Test and Johansen Cointegration Test.

Table.7. Granger Causality Test of Institutional-specific Variables and NPAs of SBI and Associate Banks in India

\begin{tabular}{|c|c|c|c|}
\hline Null Hypothesis & F - Statistic & Probability & Inference \\
\hline $\begin{array}{c}\text { GNPATA does not } \\
\text { Granger Cause CAR }\end{array}$ & 2.6560 & 0.0444 & Rejected Ho \\
\hline $\begin{array}{c}\text { CAR does not } \\
\text { Granger Cause } \\
\text { GNPATA }\end{array}$ & 3.3535 & 0.0170 & Rejected Ho \\
\hline $\begin{array}{c}\text { GNPATA does not } \\
\text { Granger Cause CRR }\end{array}$ & 11.1089 & 0.0000 & Rejected Ho \\
\hline
\end{tabular}

\begin{tabular}{|c|c|c|l|}
$\begin{array}{c}\text { CRR does not } \\
\text { Granger Cause } \\
\text { GNPATA }\end{array}$ & 7.1588 & 0.0001 & Rejected Ho \\
\hline $\begin{array}{c}\text { GNPATA does not } \\
\text { Granger Cause PLR }\end{array}$ & 22.4534 & 0.0000 & Rejected Ho \\
\hline $\begin{array}{c}\text { PLR does not } \\
\text { Granger Cause } \\
\text { GNPATA }\end{array}$ & 0.6157 & 0.6535 & Accepted Ho \\
\hline $\begin{array}{c}\text { GNPATA does not } \\
\text { Granger Cause RR }\end{array}$ & 36.7247 & 0.0000 & Rejected Ho \\
\hline $\begin{array}{c}\text { RR does not Granger } \\
\text { Cause GNPATA }\end{array}$ & 2.4223 & 0.0613 & Accepted Ho \\
\hline $\begin{array}{c}\text { GNPATA does not } \\
\text { Granger Cause RRR }\end{array}$ & 23.2125 & 0.0000 & Rejected Ho \\
\hline $\begin{array}{c}\text { RRR does not } \\
\text { Granger Cause } \\
\text { GNPATA }\end{array}$ & 5.3786 & 0.0012 & Rejected Ho \\
\hline
\end{tabular}

The Table.7 explains the findings of Granger Causality Test which delineates the association of explanatory and explained variables during the study period. From the above results, it is clear that the variables such as CAR, CRR and RRR do granger cause the GNPATA and the other 2 variables namely PLR and RR does not granger cause the GNPATA of SBI and Associate banks in India. Therefore, it is confirmed that the Capital Adequacy Ratio, Cash Reserve Ratio and Reverse Repo Rate influences the Gross Non-Performing Assets to Total Advances whereas the Prime Lending Rate and Repo Rate had no association with the GNPATA of SBI and Associate Banks in India.

Table.8. Granger Causality Test of Macroeconomic Variables and NPAs of SBI and Associate Banks in India

\begin{tabular}{|c|c|c|c|}
\hline Null Hypothesis & F - Statistic & Probability & Inference \\
\hline $\begin{array}{c}\text { GNPATA does not } \\
\text { Granger Cause IR }\end{array}$ & 9.4048 & 0.0000 & Rejected Ho \\
\hline $\begin{array}{c}\text { IR does not Granger } \\
\text { Cause GNPATA }\end{array}$ & 9.4893 & 0.0000 & Rejected Ho \\
\hline $\begin{array}{c}\text { GNPATA does not } \\
\text { Granger Cause MS }\end{array}$ & 7.5001 & 0.0000 & Rejected Ho \\
\hline $\begin{array}{c}\text { MS does not Granger } \\
\text { Cause GNPATA }\end{array}$ & 6.2753 & 0.0004 & Rejected Ho \\
\hline $\begin{array}{c}\text { GNPATA does not } \\
\text { Granger Cause UR }\end{array}$ & 13.8911 & 0.0000 & Rejected Ho \\
\hline $\begin{array}{c}\text { UR does not Granger } \\
\text { Cause GNPATA }\end{array}$ & 2.6028 & 0.0478 & Rejected Ho \\
\hline $\begin{array}{c}\text { GNPATA does not } \\
\text { Granger Cause } \\
\text { GDPGR }\end{array}$ & 19.4724 & 0.0000 & Rejected Ho \\
\hline $\begin{array}{c}\text { GDPGR does not } \\
\text { Granger Cause } \\
\text { GNPATA }\end{array}$ & 10.4381 & 0.0000 & Rejected Ho \\
\hline
\end{tabular}

The Table. 8 delineates the results of Granger Causality Test in which the relationship that exists among the study variables. It is found from the results that all the study variables are having strong association with the GNPATA. Therefore, it has been confirmed that all the 4 macroeconomic variables such as 
Inflation Rate (IR), Money Supply (MS), Unemployment Rate (UR) and Gross Domestic Product Growth Rate (GDPGR) do granger cause the Gross Non-Performing Assets to Total Advances (GNPATA) of SBI and Associate Banks in India during the study period of 10 years from 2006-07 to 2015-16.

Table.9. Johansen Co-integration Test of Institutional-specific Variables and NPAs of SBI and Associate Banks in India

\begin{tabular}{|c|c|c|c|c|c|}
\hline $\begin{array}{c}\text { Pairwise Co- } \\
\text { integration }\end{array}$ & $\begin{array}{c}\text { Eigen } \\
\text { Value }\end{array}$ & $\begin{array}{c}\text { Trace } \\
\text { Statistic }\end{array}$ & $\begin{array}{c}\text { Critical } \\
\text { Value } \\
\mathbf{5 \%}\end{array}$ & $\begin{array}{c}\text { Max- } \\
\text { Eigen } \\
\text { Statistic }\end{array}$ & $\begin{array}{c}\text { Critical } \\
\text { Value } \\
\mathbf{5 \%}\end{array}$ \\
\hline \multirow{2}{*}{ GNPATA - CAR } & 0.3008 & 36.3037 & 15.4947 & 20.7559 & 14.2646 \\
\cline { 2 - 6 } & 0.2351 & 15.5478 & 3.8415 & 15.5478 & 3.8415 \\
\hline \multirow{2}{*}{ GNPATA - CRR } & 0.5073 & 54.5899 & 15.4947 & 41.0522 & 14.2646 \\
\cline { 2 - 6 } & 0.2082 & 13.5377 & 3.8415 & 13.5377 & 3.8415 \\
\hline \multirow{2}{*}{ GNPATA - PLR } & 0.5444 & 60.7771 & 15.4947 & 45.6009 & 14.2646 \\
\cline { 2 - 6 } & 0.2302 & 15.1763 & 3.8415 & 15.1763 & 3.8415 \\
\hline \multirow{2}{*}{ GNPATA - RR } & 0.7008 & 83.6532 & 15.4947 & 69.9820 & 14.2646 \\
\cline { 2 - 6 } & 0.2100 & 13.6711 & 3.8415 & 13.6711 & 3.8415 \\
\hline \multirow{2}{*}{ GNPATA - RRR } & 0.6182 & 73.4043 & 15.4947 & 55.8504 & 14.2646 \\
\cline { 2 - 6 } & 0.2612 & 17.5539 & 3.8415 & 17.5539 & 3.8415 \\
\hline
\end{tabular}

The Table. 9 shows the results of Johansen Co-integration Test (JCT-Bivariate) of 5 institutional-specific variables and the GNPATA of SBI and Associate Banks in India during the study period. In this JCT, the Trace Statistic and Max-Eigen Statistic values are considered to identify the existence of co-integration among the study variables. It is clear from the above results that both the values are higher only for all the 5 study variables such as CAR, CRR, PLR, RR and RRR during the study period than their corresponding critical values at $5 \%$ level of significance. Thus, it ensures that all the 5 institutional-specific variables taken for the study are co-integrated with the Gross Non-Performing Assets to Total Advances (GNPATA) of SBI and Associate Banks in India.

Table.10. Johansen Co-integration Test of Macroeconomic Variables and NPAs of SBI and Associate Banks in India

\begin{tabular}{|c|c|c|c|c|c|}
\hline $\begin{array}{c}\text { Pairwise Co- } \\
\text { integration }\end{array}$ & $\begin{array}{c}\text { Eigen } \\
\text { Value }\end{array}$ & $\begin{array}{c}\text { Trace } \\
\text { Statistic }\end{array}$ & $\begin{array}{c}\text { Critical } \\
\text { Value } \\
\mathbf{( 5 \% )}\end{array}$ & $\begin{array}{c}\text { Max- } \\
\text { Eigen } \\
\text { Statistic }\end{array}$ & $\begin{array}{c}\text { Critical } \\
\text { Value } \\
\mathbf{( 5 \% )}\end{array}$ \\
\hline \multirow{2}{*}{$\begin{array}{c}\text { GNPATA - } \\
\text { IR }\end{array}$} & 0.6489 & 74.6974 & 15.4947 & 60.6994 & 14.2646 \\
\cline { 2 - 6 } & 0.2144 & 13.9980 & 3.8415 & 13.9980 & 3.8415 \\
\hline \multirow{2}{*}{$\begin{array}{c}\text { GNPATA - } \\
\text { MS }\end{array}$} & 0.3671 & 37.1915 & 15.4947 & 26.5307 & 14.2646 \\
\cline { 2 - 6 } & 0.1679 & 10.6608 & 3.8415 & 10.6608 & 3.8415 \\
\hline \multirow{2}{*}{$\begin{array}{c}\text { GNPATA - } \\
\text { UR }\end{array}$} & 0.7767 & 108.1594 & 15.4947 & 86.9487 & 14.2646 \\
\cline { 2 - 6 } & 0.3063 & 21.2108 & 3.8415 & 21.2108 & 3.8415 \\
\hline \multirow{2}{*}{$\begin{array}{c}\text { GNPATA - } \\
\text { GDPGR }\end{array}$} & 0.6798 & 81.5396 & 15.4947 & 66.0419 & 14.2646 \\
\cline { 2 - 6 } & 0.2345 & 15.4977 & 3.8415 & 15.4977 & 3.8415 \\
\hline
\end{tabular}

The Table.10 discloses the results of Johansen Co-integration Test of 4 macroeconomic variables and the non-performing assets of SBI and Associate Banks in India. The above results confirm that the Trace Statistic and Max-Eigen Statistic values are higher than their corresponding critical values at 5\% level of significance for all the 4 macroeconomic variables. Thus, it can be concluded that all the 4 macroeconomic variables such as Inflation Rate (IR), Money Supply (MS), Unemployment Rate (UR) and Gross Domestic Product Growth Rate (GDPGR) are highly cointegrated with the Gross Non-Performing Assets to Total Advances (GNPATA) of SBI and Associate Banks in India during the study period.

\subsection{SUMMARY OF FINDINGS}

The summary of the study findings is as follows:

- The Descriptive Statistics results clearly stated that the Money Supply (MS) holds the maximum mean value (6.1807) followed by Capital Adequacy Ratio (1.0941) and Prime Lending Rate (1.0387). On the other hand, the Inflation Rate has the highest standard deviation of 0.1490 queued by Money Supply (0.1437) and Reverse Repo Rate (0.1185).

- The Multiple Correlation results confirmed that the institutional-specific variables such as CAR, CRR (0.4559) and PLR (0.4121) has positive correlation among them whereas the variables like RR (-0.3906) and RRR (-0.4475) has negative relationship. Further, the Money Supply (0.7992) alone is said to be positively correlated with GNPATA whereas the other 3 macroeconomic variables such as IR (-0.5315), UR (-.2040) and GDPGR (-0.4820) are negatively correlated with the GNPATA of SBI and Associate banks during the study period of 10 years.

- The results of Augmented Dickey Fuller Test delineated that all the 5 institutional-specific variables such as CAR, CRR, PLR, RR and RRR as well as the dependent variable GNPATA are stationary (non-existence of unit root) at first difference with the integration order of $I(1)$. Further, it was found that all the 4 macroeconomic variables such as IR, MS, UR and GDPGR along with the dependent variable GNPATA are stationary as well.

- The Granger Causality Test results stated that the variables such as CAR, CRR and RRR do granger cause the GNPATA and the other 2 variables namely PLR and RR does not granger cause the GNPATA of SBI and Associate banks in India. Further, it has been confirmed that all the 4 macroeconomic variables such as Inflation Rate (IR), Money Supply (MS), Unemployment Rate (UR) and Gross Domestic Product Growth Rate (GDPGR) do granger cause the Gross Non-Performing Assets to Total Advances (GNPATA).

- The Johansen Co-integration Test results ensured that all the 5 institutional-specific variables taken for the study are cointegrated with the Gross Non-Performing Assets to Total Advances (GNPATA) of SBI and Associate Banks in India. Further, it was concluded that all the 4 macroeconomic variables such as Inflation Rate (IR), Money Supply (MS), Unemployment Rate (UR) and Gross Domestic Product Growth Rate (GDPGR) are highly co-integrated with the Gross Non-Performing Assets to Total Advances 
(GNPATA) of SBI and Associate Banks in India during the study period.

\subsection{SUGGESTIONS}

The following recommendations are made to the SBI and Associate Banks in India, based on the research findings.

- The SBI and Associates Banks in India are hereby suggested to have an eye on all these 5 institutional-specific and 4 macroeconomic variables in order to control the NPAs, as these have considerable amount of impact on it.

- Among the 9 study variables, the SBI and Associate Banks in India has to concentrate more on the movement of Capital Adequacy Ratio (CAR), Cash Reserve Ratio (CRR) and Money Supply (MS), as they are highly correlated with their Non-Performing Assets (NPAs).

- In addition to it, the SBI and Associate Banks in India can consider the movement of other variables such as Reverse Repo Rate (RRR), Inflation Rate (IR), Unemployment Rate (UR) and Gross Domestic Product Growth Rate (GDPGR) to control their level of Non-Performing Assets from time to time.

\section{CONCLUSION}

The research has been carried out to analyze the relationship that exists between the 5 institutional specific and 4 macroeconomic variables with the non-performing assets of SBI and Associate Banks in India by considering the available data for a period of 10 years from 2006-2007 to 2015-16. The various tools used for analyzing the data are descriptive statistics, augmented dickey fuller unit root test, Granger causality test and Johansen co-integration test. by applying the above research tools it was found that all the 5 institutional-specific variables such as CAR, CRR, PLR, RR and RRR along with the 4 macroeconomic variables such as IR, UR, MS and GDPGR are having significant relationship with the Gross Non-Performing Assets to Total Advances (GNPATA) of SBI and Associate Banks in India over the study period of 10 years.

\section{REFERENCES}

[1] Abhiman Das and Saibal Ghosh, "Determinants of Credit Risk in Indian State-Owned Banks: An Empirical Investigation", Available at: https://mpra.ub.unimuenchen.de/17301/1/.

[2] Yuqi Li, "Determinants of Banks' Profitability and its Implication on Risk Management Practices: Panel Evidence from the UK", Technical Report, Department of MA in Risk Management, The University of Nottingham, pp. 1-88, 2007.

[3] P I Vong and Hoi Si Chan, "Determinants of Bank Profitability in Macau", Research Project, University of Macau, 2008.

[4] Fadzlan Sufian and Royfaizal Razali Chong, "Determinants of Bank Profitability in a Developing Economy: Empirical Evidence from the Philippines", Asian Academy of Management Journal of Accounting and Finance, Vol. 4, No. 2, pp. 91-109, 2008.

[5] Ali Mirzaei and Zeynab Mirzaei, "Bank-specific and Macroeconomic Determinants of Profitability in Middle Eastern Banking", Iranian Economic Review, Vol. 15, No. 29, pp. 101-128, 2011.

[6] Fadzlan Sufian, "Profitability of the Korean Banking Sector: Panel Evidence on Bank-Specific and Macroeconomic Determinants", Journal of Economics and Management, Vol. 7, No. 1, pp. 43-72, 2011.

[7] Khizer Ali, Muhammad Farhan Akthar and Hafiz Zafar Ahmed, "Bank-Specific and Macroeconomic Indicators of Profitability-Empirical Evidence from the Commercial Banks of Pakistan", International Journal of Business and Social Science, Vol. 2, No. 6, pp. 235-242, 2011.

[8] Nagaraju Thota, "The Determinants of Commercial Banks Profitability in India", SSRN, pp. 1-19, 2013.

[9] V.E.I.W. Weerasinghe and Tissa Ravinda Perera, "Determinants of Profitability of Commercial Banks in Srilanka", International Journal of Arts and Commerce, Vol. 2, No. 10, pp. 141-170, 2013.

[10] P. Krishna Prasanna, "Determinants of Non-Performing Loans in Indian Banking System", Proceedings of $3^{\text {rd }}$ International Conference on Management, Behavioral Sciences and Economics Issues, pp. 115-118, 2014.

[11] Saikat Ghosh Roy, "Determinants of Non-Performing Assets in India-Panel Regression”, Eurasian Journal of Economics and Finance, Vol. 2, No. 3, pp. 69-78, 2014.

[12] Satyajit Dhar and Avijit Bakshi, "Determinants of Loan Losses in Indian Banks-A Panel Study", Journal of Asia Business Studies, Vol. 9, No. 1, pp. 17-32, 2015.

[13] Mahua Biswas, "Non-Performing Assets Management in State Bank of India-A Study in Barak Valley Districts of Assam", Ph.D Dissertation, Department of Commerce, Assam University, 2016.

[14] K. Thirumalaimuthu, "Non-Performing Assets Management in Banks-A Study with Reference to Select Public Sector Banks in Tirunelveli District", Ph.D Dissertation, Department of Commerce, Manonmaniam Sundaranar University, 2017. 